MAGDA WÄCHTER

\title{
THE ROMANIAN INTERWAR NOVEL. DEFINITIONAL ATTEMPTS AND CONTROVERSIES ${ }^{1}$
}

The 1930s, when artistic effervescence was at its peak, witnessed "the most fertile theoretical dispute in the history of the Romanian novel" 2 . Writers and critics of different ages and orientations defined their own positions on the matter at hand, sometimes disavowing their previous opinions or even their own creative recipes. Some realistic novelists gave precedence to psychological analysis, while others who preferred the novel of consciousness seemed to favour, at least in theory, the pure epic strain. Proustians, like Felix Aderca in some of his novels, did not always like Proust, while Gide afficionados, like Octav Şuluţiu, questioned the possibility of authenticity in literature. Critics wrote novels that did not fully correspond to their formerly held beliefs, as was the case of G. Ibrăileanu's Adela, while writers turned theorists proposed original novelistic typologies. Rarely were the debates waged on a strictly literary ground. When they were, as in the case of the "Trăirists", the participants' intention was to deny aesthetic values or to foretell the substitution of the novel with other genres or species in the near future. Most often, the favourite ground of interpretations was literary sociology, combined with ethnic psychology, philosophy or even political economy. The novel was deemed to be illustrative of literary reflection, literature was regarded as emblematic for the entire cultural landscape, while culture was symptomatic for the profile of an entire nation.

Moreover, the controversies concerned not so much the reality of the novel, already validated by representative works, such as Ion (1920) and Pădurea spânzuraţilor [The Forest of the Hanged] (1922) by Liviu Rebreanu, Concert din muzică de Bach [A Concert of Bach's Music] (1927) by Hortensia PapadatBengescu, Intunecare [Darkening] (I-II, 1927-1928) by Cezar Petrescu and many

\footnotetext{
${ }^{1}$ This article is a revised and extended version of a paper presented at the International Conference „Zilele Sextil Pușcariu” (12-13 September 2019) and published, in Romanian, in the conference proceedings (Caietele Sextil Pușcariu, 2019, 4, pp. 523-530). This is the first internationally available rendition.

${ }^{2}$ Al. Protopopescu, Romanul psihologic românesc [The Romanian Psychological Novel], București, Eminescu, 1978, p. 72.

3 "Trăirism" (from "a trăi", meaning "to live") is a pejorative term invented by the literary critic Șerban Cioculescu in order to delineate the excessive metaphysical "lived experience" promoted in the 1920s and 1930s by Nae Ionescu's so-called "mystical school of thought". The supporters of "trăirism" (among which could be mentioned Mircea Eliade and Emil Cioran) are inspired mainly by the ideas of Friedrich Nietzsche, Søren Kierkegaard, André Gide, Giovanni Papini, and José Ortega y Gasset.
} 
others, as its conditions of possibility. Aspiring to catch up with European cultural debates on the obsolescence of the genre, Romanian literary theory reached a pinnacle of development, analysing simultaneously the beginning, the zenith and the decline of Romanian novelistic fiction, from a twofold European and Romanian perspective. While critics engaged in such discussions mostly from a polemical standpoint, their arguments reflected quite accurately the contradictory situation of literature, located at the intersection of the most varied trends and orientations, at the border of other genres or species, such as the novella, the essay or the reportage, and in a cultural space that was still insufficiently clearly defined. What this debate also highlighted was a passion for denial and self-denial grafted on a native philosophical nihilism, characteristic of both traditionalism and modernism, which paradoxically converged on this aspect.

Thus, amid the controversies over the alleged non-existence of Romanian culture and literature, the emergent cultural and literary works contradicted the shortcomings that had been pointed out by the theorists. While the absence of the novel was hotly disputed, the novel thrived without disturbing the fervour of the debates. Even the problem of theoretical disputes became the object of theoretical disputes. Some of the writers, such as Camil Petrescu, complained, at that very time, about the lack of polemics, seeing this as the symptom of a worrisome literary parasitism ${ }^{4}$, while others, like Eugene Ionesco, deplored the fact that "the most significant achievement of one hundred years of Romanian groping in the dark" was "the discussion of the most significant achievement of one hundred years of Romanian groping in the dark". In any case, in the late 1920s, while the controversy regarding the conditions of possibility of the Romanian novel was very much ongoing, the whole array of novelistic forms had been experimented with, from "Sămănătorism" to the anti-novel. As Al. Protopopescu noted, the novel appeared to know his future even better than its past ${ }^{7}$.

The so-called "discord" around the crisis of the novel that began in the 1920s and continued partially in the following decade raises some legitimate question marks. N. Davidescu talked about the "agony" of a literary genre ${ }^{8}$, Felix Aderca wondered about the novel's "decline" or "decay", Eugen Ionescu spoke about the

\footnotetext{
${ }^{4}$ Camil Petrescu, "Polemicile" ["Polemics"] (1924), in Opinii şi atitudini [Opinions and Attitudes]. Anthology and foreword by Marin Bucur, București, Editura pentru Literatură, 1962, p. 168.

${ }_{6}^{5}$ Eugen Ionescu, $N u$ [No] (1934), București, Humanitas, 1991, p. 153.

6 "Sămănătorism" was a conservative, Romanticism-inspired ideology and literary movement promoted by the Sămănătorul review, in the first decade of the 20th century. Its main theoretician was the literary critic and historian Nicolae Iorga.

${ }^{7}$ Al. Protopopescu, Romanul psihologic românesc, p. 47.

${ }^{8}$ N. Davidescu, "Agonia unui gen literar" ["The Agony of a Literary Genre"] (1921), in Opinii româneşti despre roman [Romanian Perspectives on the Novel], II. Anthology by Justin Constantinescu, Octavian Lohon, Pompiliu-Mihai Constantinescu, București, Sigma, 2009, pp. 26-28.

${ }^{9}$ Felix Aderca, "Descompunerea unui gen literar" ["The Decay of a Literary Genre"] (1928), in Opinii româneşti despre roman, II, pp. 153-155.
} 
"death" of the novel ${ }^{10}$, Mihai Ralea wondered why Romanian literature did not have novels ${ }^{11}$, and so did Nicolae Iorga in an article from $1890^{12}$. On the other hand, Perpessicius celebrated the flourishing of the novel in 1925, noting ironically that it had always been the nightmare of Romanian literature, or "better said, the American uncle everyone is talking about and waiting for and who is never going to arrive" ${ }^{13}$. The subtlety of the interpretations and classifications, the intervention of novelists turned critics and essayists attested, beyond the actual reality of the literary works, a theoretical complexity that far exceeded the question whether there were any good novels in Romanian literature. Writers and critics spoke, while trying to answer the initial question, about Proustianism, Gideanism, intuitionism, phenomenology, existentialism, the indirect novel, the parodic novel, the novel of ideas or the pure novel. Ibrăileanu's dichotomy between creation and analysis led to original distinctions, formulated by the novelists themselves, between dynamic and static novels (Anton Holban) ${ }^{14}$ or between observative and resolutive literature (Ionel Teodoreanu) ${ }^{15}$.

Romanian literature seemed fully synchronised with European literature in theory, especially since the very problem of the crisis of the novel lay under the sign of this synchronisation. However, the question of the non-existence of the novel in our literature followed a traditionalist, "Sămănătorist" line, anticipated by N. Iorga' ideas, with even older roots. In an article from 1890, N. Iorga asked "Why don't we have a novel?". He identified the same causes that were to be highlighted a few decades later: the indifference of the public, the social circumstances of the artist's life, the lack of professional writers and critics, and the limited range of themes, revolving around "brigandry", "fantasy pessimism" and pornography ${ }^{16}$. Speaking from a "Sămănătorist" perspective, Iorga criticised the Romanian novel in almost Lovinescian terms, concluding that "in order for it to live, it needs an eminently modern social category" ${ }^{\prime 17}$. Advocating a transition from

\footnotetext{
${ }^{10}$ Eugen Ionescu, "Moartea de mâine a romanului" ["The Novel's Upcoming Death"] (1934), in Război cu toată lumea. Publicistică românească [At War with Everybody. The Romanian Journalistic Writings], I. Edited and bibliography by Mariana Vartic and Aurel Sasu, București, Humanitas, 1992, pp. 61-62.

${ }^{11}$ Mihai Ralea, "De ce nu avem roman?" ["Why Don't We Have a Novel?"] (1927), in Opinii româneşti despre roman, II, pp. 121-129.

12 Nicolae Iorga, "De ce n-avem roman?" ["Why Don't We Have a Novel?"] (1890), in Opinii româneşti despre roman, I, pp. 244-249.

${ }^{13}$ Perpessicius, "Înflorirea romanului" ["The Blossoming of the Novel”] (1925), in Opinii româneşti despre roman, p. 58.

${ }^{14}$ Anton Holban, "Testament literar" ["Literary Testimony"] (1937), in Romanul românesc interbelic. Dezbateri teoretice, polemici, opinii critice [The Romanian Interwar Novel. Theoretical Debates, Polemics, Critical Opinions]. Anthology, foreword, critical analyses, notes, dictionary, chronology and bibliography by Carmen Muşat, București, Humanitas, 1998, p. 75.

15 Dinu Pillat, Mozaic istorico-literar. Secolul XX [A Literary-Historical Mosaic. The Twentieth Century], București, Editura pentru Literatură, 1969, pp. 33-35.

${ }^{16}$ Nicolae Iorga, “De ce n-avem roman?”, pp. 244-249.

${ }^{17}$ Ibidem, p. 247.
} 
rural to urban themes and from social to consciousness issues, Eugen Lovinescu made similar accusations against "the world of outlaws and horse thieves" or "the stories of old men smoking their pipes, in the half light of dusk"18. Two opposing literary formulas came together to ascertain the absence or failings of the novel. The same happened a few decades later, except that the divergent literary trends were more numerous, the reasons were also more varied, and the solutions were often disconcerting. What, then, were the causes, symptoms and remedies of the alleged crisis of the novel reported in the third and fourth decades of the twentieth century? If there really was a crisis, what did it consist of?

The first argument that was put forward was a purely quantitative one: we have too few novels. While, at the end of the nineteenth century, N. Iorga considered himself perhaps too generous by stating that "we have at most six novels that can be read"19, the situation did not seem to be very different to some writers even a few decades later. In 1934, Eugen Ionescu predicted the death of the novel in no more than ten years, noting that barely ten literary books written after 1920 deserved recognition ${ }^{20}$. Even in 1938, after the publication of the great Romanian fictional narratives, there were voices that said that "the Romanian novelist does not know what a novel is". This statement belonged to G. Călinescu ${ }^{21}$.

Other analysts of the problem, such as Tudor Arghezi, foresaw, on the contrary, the danger of mediocrity arising from the abundance of novels that were written at that time, claiming that there were "so many novelists and so few writers" 22 . Given "the unexpected surge of novels in recent years", G. Călinescu emphasised the ineptitude of our literary critics, concluding, in a 1934 text, that "if Anatole France had been Romanian, he could not have made a career here", and that "if it were judged by the measures of our critics, all world literature would be greatly diminished"23. This time, it was not about the lack of novels, but about the incompetence of critics, to which was added the readership's unpreparedness for the novel and for literature in general. In the aforementioned article from 1890, N. Iorga also noticed the indifference of a Frenchified readership, accustomed to reading foreign literature. At the opposite end, Mihai Ralea considered that readers lacked appropriate skills because of the Romanians' social and cultural backwardness. Vehement polemicists, like Emil Cioran or Eugen Ionescu, ridiculed the Romanian public's lack of appetite for culture, for the higher forms of thinking

\footnotetext{
${ }^{18}$ Eugen Lovinescu, Istoria literaturii române contemporane [History of Contemporary Romanian Literature] (1926), II, București, Minerva, 1973, pp. 209-210.

${ }^{19}$ Nicolae Iorga, "De ce n-avem roman?", p. 246.

${ }^{20}$ Eugen Ionescu, "Anul literar 1934 şi ceilalţi ani" ["The Literary Year 1934 and the Other Years"] (1934), in Război cu toată lumea, p. 68.

${ }^{21}$ G. Călinescu, "Câteva cuvinte despre roman" ["A Few Words about the Novel”] (1938), in Opinii româneşti despre roman, II, p. 497.

${ }^{22}$ Tudor Arghezi, "Roman, roman...” [“Novel, Novel..."] (1933), in Opinii româneşti despre roman, II, p. 308.

${ }^{23}$ G. Călinescu, "Nici o graniţă" [“No Borders”] (1934), in Opinii româneşti despre roman, II, p. 375.
} 
as a whole. On the other hand, Camil Petrescu, N. Davidescu and Ion Vinea invoked the discrepancy between the outdated habit of reading novels and the fast pace of modern life. In 1918, the follower of intuitionism and phenomenology wondered:

Who has the patience to read a novel today? Who even has time to read a novel? Old maids, country maids, war invalids, students in boarding school and a few other categories of their kind! [...] The age of electricity, airplanes and automobiles no longer affords time for novels to be written and read ${ }^{24}$.

An obsolete genre, the novel was about to fade, just like the epic, the fable or the ancient epigram, being replaced by the theatre. Convinced, in turn, that the novel "no longer belongs to our era", Ion Vinea predicted in 1925 its substitution with the reportage or the poem-novel ${ }^{25}$. Pericle Martinescu, convinced that the readers' standards had risen, went even further, recommending the replacement of the genre with music, which was much more appropriate to the modern taste ${ }^{26}$. The discrediting of the novel as a sovereign literary genre and its replacement with the short story were also foreshadowed by Ovid Densusianu in 1921, who blamed this on the reading public, more precisely on the predominantly female readership. With the emancipation of women and their participation in real life, the critic explained, escapist reading would inevitably lose its appeal ${ }^{27}$.

Thus, in the opinion of many writers and theorists, the novel was nearing its end, because of its numerical precarity or because of an overabundance of published works, because of an audience that was either unfit for culture or too evolved to be content with mere reading. In the same decade, in a 1932 note, G. Călinescu complained that the "Romanian youth do not read literary books of any kind" 28 . On the contrary, Mihail Sebastian expressed his dissatisfaction that reading was such a widespread phenomenon of the times that it had come to replace living itself $^{29}$.

Whether or not there were good novels, readers and critics remained, for the time being, uncertain. The fact is that there was no consensus between writers and society. Neither did the creator enjoy favourable conditions for creation, nor did society benefit from the active and effective participation of the creator. The work

\footnotetext{
${ }^{24}$ Camil Petrescu, "Între dramă şi roman” ["Between Drama and Novel”] (1918), in Opinii româneşti despre roman, I, p. 513.

${ }^{25}$ Ion Vinea, "Romanul" ["The Novel"] (1925), in Opinii româneşti despre roman, II, p. 49.

${ }^{26}$ Pericle Martinescu, "Improvizații pe tema crizei romanului" ["Sketches on the Crisis of the Novel"] (1938), in Opinii româneşti despre roman, II, pp. 505-506.

${ }^{27}$ Ovid Densusianu, "Viitorul romanului" ["The Future of the Novel"] (1921), in Opinii româneşti despre roman, II, pp. 23-25.

${ }^{28}$ G. Călinescu, Gâlceava înţeleptului cu lumea. Pseudojurnal de moralist [The Quarrel of the Wise Man with the World. Pseudo-diary of a Moralist], I (1927-1939), București, Minerva, 1973, p. 95.

${ }^{29}$ Mihail Sebastian, "Scurt pamflet împotriva omului literar" ["A Short Pamphlet against the Man of Letters"] (1931), in Eseuri, cronici, memorial [Essays, Chronicles, Memorial]. Edited and foreword by Cornelia Ştefănescu, București, Minerva, 1972, pp. 683-685.
} 
of the novelist, Iorga warned in the 1890s, demands sacrifice, time, consistency and requires a certain way of life, i.e., "a time to write, a specific number of pages to be written every day, some rest for the animal machine, and nothing else" 30 . According to Cezar Petrescu, the reason why we had so many talented storytellers but no novelists was because the novel involved contact with life, and Romanian writers were usually divorced from society, isolated in the world of cafes or literary soirees. Unable to make a living from writing, they were forced to do journalism, "to doze off in an office, to waste their energy and freshness of thought, elsewhere than in literature", saving only "the crumbs" for creation ${ }^{31}$. There could be added other vices as well, such as the mirage of luxury and the noisy glory that had replaced genuine intellectual concerns, a phenomenon that was to be exposed by G. Călinescu almost ten years later ${ }^{32}$ or the envy and petty rivalry between the writers, incited by Camil Petrescu ${ }^{33}$. As for the Romanian society and its adherence to aesthetic values, the situation seemed to be really worrying, not only in the view of modernists, but also in that of more conservative spirits. Advocating for the social novel, meant to mirror the future development of our literature, G. Ibrăileanu lamented in 1919 the simplicity of our social life, the insufficiently broad cultural horizons and the lack of a Romanian literary tradition ${ }^{34}$.

Was, then, the social novel the sole chance of our literature? Was the Romanian society mature enough to support the rise of the novel? Did our novel stand to gain from a reality pact? The sociological arguments advanced by Mihai Ralea in his well-known essay of 1927, "Why don't we have a novel?", provide an answer of perfect sceptical clarity. Analysed in terms of its psychological, ethnic, social and cultural determinants, the novel would have little success in our literature, according to Ralea the critic. In his opinion, we lacked a tradition of the genre, namely the epic; the cultural framework was non-existent, and the social one left much to be desired. If the novel appeared as a result of the invention of printing and the dominance of the middle classes, in Romania this class did not exist before the end of the nineteenth century. The Oriental-agrarian structure of our society, devoid of a cultivated public and indebted to a primitive, collective, gregarious mentality, had rendered impossible the development of a genre that favoured the individual over the masses, complexity over uniformity, and character development over atmosphere. To all this would be added elements characteristic of our ethnic psychology. By its nature, the novel presupposed a dramatic conflict that

\footnotetext{
${ }^{30}$ Nicolae Iorga, "De ce n-avem roman?", p. 248.

${ }^{31}$ Cezar Petrescu, "Roman românesc" ["Romanian Novel"] (1923), in Opinii românești despre roman, II, p. 35.

32 G. Călinescu, "Romanul şi viaţa modernă" ["The Novel and the Modern Life"] (1932), in Opinii românești despre roman, II, p. 236.

${ }^{33}$ Camil Petrescu, "Scriitorii între ei" ["Writers by Themselves"] (1925), in Opinii şi atitudini, p. 172.

${ }^{34}$ G. Ibrăileanu, "Literatura de mâine" ["The Forthcoming Literature"] (1919), in Opinii româneşti despre roman, I, p. 519.
} 
determined the destiny of the hero, yet what predominated in our social life was not the struggle, but the "transactional spirit of compromise". "We adapt and reconcile too easily", the critic concluded, adding that we are "too kind-hearted, too weak, too easily forgetful or forgiving" and that life in our country is limited to being "easy, comfortable, enjoyable" ${ }^{35}$. Such a society is naturally reflected in the world of literary characters, critiqued especially by modernist writers such as by Camil Petrescu:

One cannot produce novels or even literature if all there is are heroes who eat five olives for three weeks or who smoke a cigarette for two years, a tavern in a mountain borough and a three-coop household of a teacher from Moldova. Literature naturally tackles problems of conscience ${ }^{36}$.

"A snobbery that is characteristic of our rural nation" lay at the origin of these claims, as G. Călinescu polemically added ${ }^{37}$, although on other occasions he himself condemned the mundane mentality of Romanian literature and the writers' lack of interest in ideal values.

Another indictment of the characters that prevailed in Romanian novels was undertaken by Mircea Eliade in the next decade, to support the need for a theoretical consciousness of the world:

I do not know if there is in Romanian literature a single character who committed suicide out of despair or because of a simple metaphysical drama. But there are many who have committed suicide out of love, or boredom, or hunger. In the Romanian novel, there is no mystic, no exalted or cynical man. The drama of existence does not descend to the roots of being. Romanian characters are still far from fighting in the great contemporary battle for freedom, human destiny, death and failure ${ }^{38}$.

In Eliade's opinion, the solution would be myth-characters, exemplified solely by Liviu Rebreanu's Ion. Thus, the novel would not have much to gain on the social field, in the context of our culture's "anti-urban" mentality, as Şerban Cioculescu called it in a polemical text on the gallery of local Romanian characters, composed of "boyars and boyars' wives, draped in kindness and philanthropy, peasants who rejoice that the scale of justice is well-balanced, greedy townsmen alienated from their peasant roots, clerks turned into automatons by their routine jobs and intellectuals without moral support, etc." ${ }^{39}$. It was not the theoretical consciousness of the world that the hero or the author lacked, in the opinion of the

\footnotetext{
${ }^{35}$ Mihai Ralea, “De ce nu avem roman?”, pp. 121-129.

${ }^{36}$ Camil Petrescu, "De ce nu avem roman" ["Why We Don't Have a Novel"] (1936), in Opinii româneşti despre roman, II, p. 130.

${ }^{37}$ G. Călinescu, "Camil Petrescu, teoretician al romanului" ["Camil Petrescu, Theorist of the Novel"] (1939), in Opinii româneşti despre roman, II, p. 513.

${ }^{38}$ Mircea Eliade, Fragmentarium (1939), București, Humanitas, 2008, p. 91.

${ }^{39}$ Şerban Cioculescu, "Romanul românesc 1933" ["The Romanian Novel of 1933"] (1934), in Opinii româneşti despre roman, II, p. 336.
} 
critic, but much less than that: the elementary lucidity necessary for seeing the world clearly. The only Romanian writer who could have been a truly talented novelist was Ion Luca Caragiale. Unfortunately, he did not write novels, Cioculescu concluded $^{40}$. In his plea for the subjective novel, Pompiliu Constantinescu also believed that the social novel did not represent the future, but the past of the Romanian novel ${ }^{41}$.

Most disputes were waged between the objective and the subjective model, between the realistic and the psychological novel (with different variations), in line with the distinction proposed by G. Ibrăileanu. As a rule, modernist writers and critics leaned towards the Ionic model of the novel, while traditionalists opted for the Doric $\mathrm{c}^{42}$. However, there were many exceptions and visions that transcended this separation. Marcel Proust, for example, much discussed in Romanian literary journalism, was the novelistic model par excellence for Camil Petrescu, while for Felix Aderca - also a modernist writer - he was the main culprit for the demise of the novel ${ }^{43}$. While some authors adopted the Proustian conception early on, others, like Al. Philippide, believed that the psychological novel "is against the nature of our literature, therefore against the nature of the Romanians, who resolutely reject the dry and precise analysis" and "metaphysical-moral speculations"44. G. Călinescu's reluctance to embrace Proustianism is well known. In the opinion of the great critic, what the Romanian writers lacked was not analytical virtuosity, but contact with life:

It would seem that the Romanian writer does not live his life and, in most cases, this is true. Our novelist is a man of letters, a craftsman who takes a theme, just like the blacksmith takes a rod of iron, heats it, beats it, twists it, finally gives it a regular form, but the metal with which he works is a substance inadequate to the object he makes, so everything boils down to the level of an abstract exercise ${ }^{45}$.

It is difficult to ascertain the situation of the Romanian novel between the two World Wars and to identify what its alleged precarity in relation to other literary species and the Western novel resided $\mathrm{in}^{46}$. Was it a phenomenon of decay and agony, or one of overabundant creation? Did people read too much or too little?

\footnotetext{
${ }^{40}$ Ibidem.

${ }^{41}$ Pompiliu Constantinescu, "Realism şi construcţie epică în roman" ["Realism and the Narrative Construction of the Novel"] (1943), in Opinii româneşti despre roman, II, pp. 562-564.

${ }^{42}$ According to Nicolae Manolescu in Arca lui Noe. Eseu despre romanul românesc [Noah's Arch. Essay on the Romanian Novel], I-III, Bucuresti, Minerva, 1980-1983, the "doric" stands for the traditional model of the novel, while the "ionic" represents the psychological modern novel. The third model of the novel, namely the "corintic" one, is specific to the fragmentary and relativist postmodern fiction.

${ }^{43}$ See Felix Aderca, "Descompunerea unui gen literar", pp. 153-155.

44 Alexandru Philippide, "Tradiţia literară românească" ["The Romanian Literary Tradition”] (1936), apud Romanul românesc interbelic, p. 24.

${ }^{45} \mathrm{G}$. Călinescu, "Romanul şi viaţa modernă", p. 235.

${ }^{46}$ See also Andrei Terian, "Big Numbers: A Quantitative Analysis of the Development of the Novel in Romania", Transylvanian Review, 28, 2019, 1, pp. 55-71.
} 
Did we or did we not have a competent set of literary reviewers and a readership that was receptive to aesthetic values? Can we speak of a certain primitivism of Romanian culture, reduced to the problem of "brigandry", in Nicolae Iorga's terms, in a literary context marked by debates about Proustianism, Gideanism, existentialism and phenomenology? Did the Romanian novelist lack experience, contact with life, the support of the state, lucidity, character, culture or the theoretical consciousness of the world? Modernists generally accused our "rural" traditionalism, conservatives ridiculed the "fashion" of Europeanism and the "evils" of the modern world; philosophers speculatively reconstructed the decline of the genre, starting from the era of German idealism, and sociologists described a Romanian world that did not lend itself easily to fictionalisation in the novel. Nihilists like Emil Cioran or Eugen Ionescu denounced in metaphysical terms the relativity of the novel - inevitably impure genre and stated that, ultimately, any creation belonged exclusively to the divine.

In parallel with the discussion about the conditions of possibility for the Romanian novel, the prospect of a return to the forms of the pure epic was advanced, in light of the exhaustion of innovative, metaphysical or analytical formulas. Cezar Petrescu, for instance, pleaded for a return to the chronicle type of novel $^{47}$; like Mircea Eliade, Paul Zarifopol suggested the detective novel, which could be the "saving solution for a humanity that is administered, in marketable doses, flaccid literature under the pretext of psychological depth" ${ }^{4}$; Al. Philippide noted that the traditional adventure novel was the only species not cultivated in our literature. For Al. Philippide, as for Ovidiu Papadima, the absence of the great Romanian city from the novel was one of the drawbacks of this form of narrative ${ }^{49}$. In the opinion of Mihail Sebastian, the lack of representations of the province in the Romanian novel was another major problem ${ }^{50}$.

Besides the solutions addressing the typology, framework and themes of the novel, other suggestions as to how to put an end to the crisis of the novel were aimed at changing the narrative perspective as a whole and revising the entire novelistic concept. For instance, Mihail Sebastian recommended, inspired by André Gide, the pure novel of the free acts, that is, "the event without consequences, without teachings, without poems, without any other meaning than that of mere anecdotal relationships" ${ }^{\prime 51}$. He explained that the erotic, historical, pastoral, naturalistic, realistic or romantic novel had all laid emphasis to a far

\footnotetext{
47 Cezar Petrescu, "Romanul cronică, roman trăit" ["The Novel as Chronicle, the Novel as Experience"] (1934), in Opinii româneşti despre roman, II, pp. 348-349.

48 Paul Zarifopol, "Literatura onestă" ["Honest Literature"] (1934), in Opinii româneşti despre roman, II, p. 346.

${ }^{49}$ Alexandru Philippide, "Romanul de aventuri şi societatea românească" ["The Adventure Novel and the Romanian Society"] (1938), in Opinii românești despre roman, II, pp. 468-469.

${ }^{50}$ Mihail Sebastian, "Dosar de creaţie. Jurnal de roman" ["Creative Report. A Novel's Log"] (1929), in Opinii româneşti despre roman, II, pp. 182-184.

${ }^{51}$ Mihail Sebastian, Eseuri, cronici, memorial, p. 46.
} 
greater extent on "psychology, moral, idyll, poetry, philosophy and history than on story and storytelling" 52 . In a different register, Vladimir Streinu proposed the solution of the so-called "novel novel", likely to strike the right balance between inner and outer dynamics, between psychological analysis and pure narrativity ${ }^{53}$. "Confessionalism", the "penchant for analysis", "resolutive" and "observative" literature, pure novel, novel-poem, and the novel novel were just some of the formulas that contradicted G. Călinescu in his conviction that the Romanian novel itself was missing from Romanian literature or that Romanian criticism was petty, "full of personal insults, conventional and disproportionate adulation, ignorance or blatant bad faith" 54 . The critic complained about the "negative storms" that ravaged our literary press and recommended a breath of "understanding and generosity" 55 . As regards the question of the crisis of the novel, he ironically suggested a specific theme, derived from the great literary works and treatises, namely: the history of the young man who wanted to get to live by all means and subordinated all his emotions to this passion, the history of the ambitious, idealistic man, ready to face any set-backs on his road to glory, the history of the unsatisfied woman, the history of the middle-aged man tired of his marriage, etc. ${ }^{56}$. Even more acerbically, Tudor Arghezi offered a recipe for the novel that would guarantee its success: a novel "must feature at least two people of the opposite sex, forming a couple, mixed with a comic character, plus a tragic one, with a prodigal man and a miser, and among them some fish, some saints and some rascals and a great virtue". Then, the presentation of extras, the furniture, the scenery, a psychological analysis and, at the end, "suicide, accident, madness or regrets" 57.

Constantly oscillating between seriousness and playfulness, between affirmative impulses and passionate scepticism, the analysis of the novel undertaken in the third and fourth decades of the twentieth century fully confirmed the existence, variety and magnitude of the epic creation itself. Neither the novel, nor the criticism or the reading public were missing from our literature; neither the great city, nor the province were nowhere to be found; neither the inventiveness, nor the analytical or the metaphysical spirit were absent from the novels of this period. Romanian writers did demonstrate they possessed lucidity and humour. All those discussions about the non-existence of the novel simply affirmed the existence of the novel, in a spirit of "discord" that proved to be very favourable to Romanian novelistic endeavours.

\footnotetext{
${ }^{52}$ Ibidem.

${ }^{53}$ Vladimir Streinu, "Romanul roman" ["The Novelistic Novel"] (1935), in Opinii româneşti despre roman, II, pp. 387-391.

${ }^{54}$ G. Călinescu, Gâlceava înţeleptului cu lumea, p. 33.

${ }^{55}$ Ibidem, p. 34.

${ }^{56}$ G. Călinescu, "Câteva cuvinte despre roman", p. 498.

${ }^{57}$ Tudor Arghezi, "Roman, roman...”, p. 309.
} 


\section{BIBLIOGRAPHY}

***, Opinii româneşti despre roman [Romanian Perspectives on the Novel]. Anthology by Justin Constantinescu, Octavian Lohon and Pompiliu-Mihai Constantinescu, București, Sigma, 2009.

***, Romanul românesc interbelic. Dezbateri teoretice, polemici, opinii critice [The Romanian Interwar Novel. Theoretical Debates, Polemics, Critical Opinions]. Anthology, foreword, critical analyses, notes, dictionary, chronology and bibliography by Carmen Muşat, București, Humanitas, 1998.

CĂLINESCU, G., Gâlceava ințeleptului cu lumea. Pseudojurnal de moralist [The Quarrel of the Wise Man with the World. Pseudo-diary of a Moralist], I (1927-1939), București, Minerva, 1973.

ELIADE, Mircea, Fragmentarium, București, Humanitas, 2008.

IONESCU, Eugen, $\mathrm{Nu}[\mathrm{No}$ ], București, Humanitas, 1991.

IONESCU, Eugen, Război cu toată lumea. Publicistică românească [At War with Everybody. The Romanian Journalistic Writings], I. Edited and bibliography by Mariana Vartic and Aurel Sasu, București, Humanitas, 1992.

LOVINESCU, Eugen, Istoria literaturii române contemporane [History of Contemporary Romanian Literature], II, București, Minerva, 1973.

MANOLESCU, Nicolae, Arca lui Noe. Eseu despre romanul românesc [Noah's Arch. Essay on the Romanian Novel], I-III, București, Minerva, 1980-1983.

PETRESCU, Camil, Opinii şi atitudini [Opinions and Attitudes]. Anthology and foreword by Marin Bucur, București, Editura pentru Literatură, 1962.

PILLAT, Dinu, Mozaic istorico-literar. Secolul XX [A Literary-Historical Mosaic. The Twentieth Century], București, Editura pentru Literatură, 1969.

PROTOPOPESCU, Al., Romanul psihologic românesc [The Romanian Psychological Novel], București, Eminescu, 1978.

SEBASTIAN, Mihail, Eseuri, cronici, memorial memorial [Essays, Chronicles, Memorial]. Edited and foreword by Cornelia Ştefănescu, București, Minerva, 1972.

TERIAN, Andrei, "Big Numbers: A Quantitative Analysis of the Development of the Novel in Romania", Transylvanian Review, 28, 2019, 1, pp. 55-71.

\section{THE ROMANIAN INTERWAR NOVEL. DEFINITIONAL ATTEMPTS AND CONTROVERSIES}

\section{(Abstract)}

Inspired by the European debates, Romanian literary theory focused on the problem of the novel during the fourth and the fifth decades of the twentieth century. Critics and prose writers representing different artistic directions came together to disapprove of the Romanian novel from a philosophical, social or ethnical perspective rather than from a literary one. While both traditionalists and modernists brought into question the very existence of the local epic creation, the latter succeeded in illustrating most of the modern trends and reached full maturity. Therefore, the theoretical dispute on the conditions of the novel seemed to suggest a nihilist passion specific to both traditional and modern Romanian literary thinking.

Keywords: novel, interwar, polemics, nihilism, literary theory. 


\section{ROMANUL ROMÂNESC INTERBELIC. ÎNCERCĂRI DE DEFINIRE ȘI CONTROVERSE (Rezumat)}

Inspirată de dezbaterile din spaţiul cultural occidental, teoria literară românescă din deceniile al patrulea şi al cincilea ale secolului trecut ia în discuţie problema romanului. Critici şi prozatori de orientări din cele mai diverse se întâlnesc pentru a-şi exprima reticenţa faţă de această specie, mai curând din punct de vedere filosofic, social şi etic decât literar. În timp ce tradiţionaliştii şi moderniştii pun sub semnul întrebării însăşi existenţa romanului, acesta îşi află maturitatea deplină, abordând majoritatea formulelor narative la modă. Astfel, disputa teoretică pe marginea condiţiilor de posibilitate ale romanului sugerează mai degrabă o vervă nihilistă specifică deopotrivă tradiţionalismului şi modernismului românesc.

Cuvinte-cheie: roman, interbelic, polemică, nihilism, teorie literară. 